\title{
UDDER MORPHOLOGICAL TRAITS AND MILK YIELD OF CHILOTA AND SUFFOLK DOWN SHEEP BREEDS
}

\author{
María E. Martínez ${ }^{*}$, Cecilia Calderón², Rodrigo de la Barra², L. Fernando de la Fuente ${ }^{3}$ \\ and Carlos Gonzalo ${ }^{3}$
}

\begin{abstract}
Morphological traits of the whole udder (circumference, width, height, and length), teats (angle, length and width), udder cistern (teat opening and cistern height), and milk yield were measured over one lactation in a total of 18 ewes (nine Chilota and nine Suffolk Down sheep) belonging to the same experimental flock (Centro Experimental INIA Butalcura, Chiloé, Chile). Analysis of variance showed significant effects for breed, sheep within breed, and stage of lactation. Chilota ewes evidenced greater udder circumference $(433 \mathrm{~mm})$, udder length $(86 \mathrm{~mm})$, teat opening $\left(96^{\circ}\right)$, and milk yield $\left(947 \mathrm{~mL} \mathrm{~d}^{-1}\right)$ than Suffolk Down ewes $\left(410 \mathrm{~mm}, 77 \mathrm{~mm}, 93^{\circ}\right.$, and $559 \mathrm{~mL} \mathrm{~d}^{-1}$, respectively). Udder circumference, udder width, udder length, cistern height and teat size significantly decreased throughout lactation. Repeatabilities of all traits were between 0.17 and 0.60 ; the highest repeatability was for udder circumference. This trait is easy to measure and had a discriminatory value for breed differentiation. In conclusion, Chilota sheep had a dairy aptitude greater than Suffolk Down sheep and similar to Spanish and Mediterranean dairy sheep breeds at beginning of their breeding programs.
\end{abstract}

Key words: Mammary morphology, teats, dairy, sheep.

\section{INTRODUCTION}

The relationship between udder traits, milkability, milk yield and mammary health are known for cattle (Seykora and McDaniel, 1986; Rogers and Spencer, 1991). The factors affecting these udder traits, their heritabilities and methodologies have also been investigated in this species (Vinson et al., 1982; Seykora and McDaniel, 1985). Results from those studies have contributed to improvements in mammary morphology and aptitude for machine milking through adequate selection programs.

The morphological traits of sheep udder have been researched in Mediterranean breeds, particularly in dairy sheep breeds, such as Churra (Fernández et al., 1995; De La Fuente et al., 1996), Lacaune (Marie-Etancelin et

${ }^{1}$ Praderas Chiloé Ltda., sector Degañ S/N, Ancud, Chiloé, Chile. *Corresponding author (memarp@unileon.es).

${ }^{2}$ Instituto de Investigaciones Agropecuarias INIA, O'Higgins 415-A, of. 14, Castro, Chiloé, Chile.

${ }^{3}$ Universidad de León, Dpto. Producción Animal, Campus de Vegazana S/N, 24071, León, España.

Received: 3 July 2010.

Accepted: 5 October 2010. al., 2005) and Sarda (Casu et al., 2006), but not in meat breeds. The study of mammary morphological traits in meat breeds and their relationship with milk production should be of special interest for rearing ability, and also for knowing dairy potentiality and yield diversification of some breeds traditionally considered for meat purpose. This could be the case of Chilota sheep, indigenous of Chiloé archipelago, Chile, devoted to lamb production in extensive conditions, but genetically related with Spanish dairy sheep, as the Churra and Castellana (De la Barra et al., 2010). In this context, the study of mammary morphological traits and their main variation factors and repeatabilities in Chilota breed, could permit to know its dairy potentiality, as well as to identify those mammary traits more suitable for specific breeding programs. Yield diversification could result in a revaluation of sheep sector because of the possibility of dairy products manufacture. Sheep milk is a high fat, high protein product, mainly used in handmade produced or industrially quality cheeses, curds or yoghourts, which are highly valued for consumers and local markets. This should permit an economic optimization for autochthonous sheep breeding in the archipelago, as well as an increase of economic return for producers. 
The objectives of this research were to study the morphological traits of the mammary gland and milk yield, as well as the main variation factors and repeatabilities of these traits in Chilota and Suffolk Down breeds. Suffolk Down sheep was included in this study as control because it is currently present in Chiloé archipelago as breed specialized in meat production.

\section{MATERIALS AND METHODS}

The study was carried out in 18 sheep belonging to same experimental flock (Centro Experimental INIA Butalcura, Chiloé, Chile): nine Chilota sheep and nine Suffolk Down sheep; all ewes were in second parity and had a single birth (one lamb per partum). Lambs were separated from their mothers for $12 \mathrm{~h}$ before the corresponding measurements of morphological traits and milk yield, to provide the appropriate period for milk secretion. Four measurements per lactation were taken from all ewes at 15, 45, 75, and $105 \mathrm{~d}$ postpartum.

The methodology used for measuring mammary parameters were those described by Labussière et al. (1981), which was the reference method used within the M4 project of Food and Agricultural Organization to study the dairy aptitude and milking suitability of main Mediterranean sheep breeds (Labussière, 1983). In the present study, the udder volume measurement was replaced by width, length, height, and circumference of the udder because the latter traits are more accurate and easier to measure than udder volume, according to Gonzalo (1984) and Iñiguez et al. (2009). The morphological traits studied (Figure 1) were: udder circumference, width, height and length; width at the base, width at the medium point and length of the right teat; angle of right and left teats, sum of two angles or teat opening, and height of right and left cisterns. Udder circumference was measured with ribbon tape and other measures, except teat angle and cistern height, were made with caliper. Teat angle was measured from rear view in degrees from vertical. Finally, the cistern heights were measured from a rear view picture, estimating the height by means of a reference measure; the cistern height in each picture was the vertical measure between the lower teat insertion and the lower point of the cistern.

In addition, milk yield was estimated in each test-day observation immediately after mammary morphology measurement, by the method of double injection of oxytocin, according to the methodology of Doney et al. (1979). Briefly, the udder was completely emptied by hand milking after a first injection of oxytocin (3 UI via intrajugular), and this process was repeated $4 \mathrm{~h}$ later with the objective of obtaining the milk produced in this interval. The milk yield potential in each control and animal was estimated multiplying by 6 the milk volume obtained in that $4 \mathrm{~h}$ interval.

Feeding of all animals was based on grazing on natural prairies $\left(9 \mathrm{t} \mathrm{MS} \mathrm{ha}^{-1} \mathrm{yr}^{-1}\right)$, supplemented with 100 $\mathrm{g}$ oats grain, $300 \mathrm{~g}$ of Lolium perenne-Trifolium repens silage and $500 \mathrm{~g}$ of grass hay $40 \mathrm{~d}$ before probable date of birthing and $30 \mathrm{~d}$ after lambing.

\section{Statistical analyses}

According with Fernández et al. (1995), the data were analyzed by least squares means techniques using the GLM procedure of SAS (2008). The variation factors of morphological traits and milk yield were the breed, the ewe within breed, and the stage of lactation. The statistical model used was:

$$
\mathrm{Y}_{\mathrm{ijk}}=\mu+\mathrm{B}_{\mathrm{i}}+\mathrm{E}_{\mathrm{j}(\mathrm{i})}+\mathrm{L}_{\mathrm{k}}+\mathrm{e}_{\mathrm{ijk}}
$$

where $Y_{\mathrm{ijk}}=$ dependent variables studied, such as udder circumference, length, width, and height; length, width at the base, and width at medium point of teat; teat angle and opening; cistern height, and milk yield; $\mu=$ mean; $\mathrm{Bi}=$ effect of breed (two levels: Chilota and Suffolk Down);
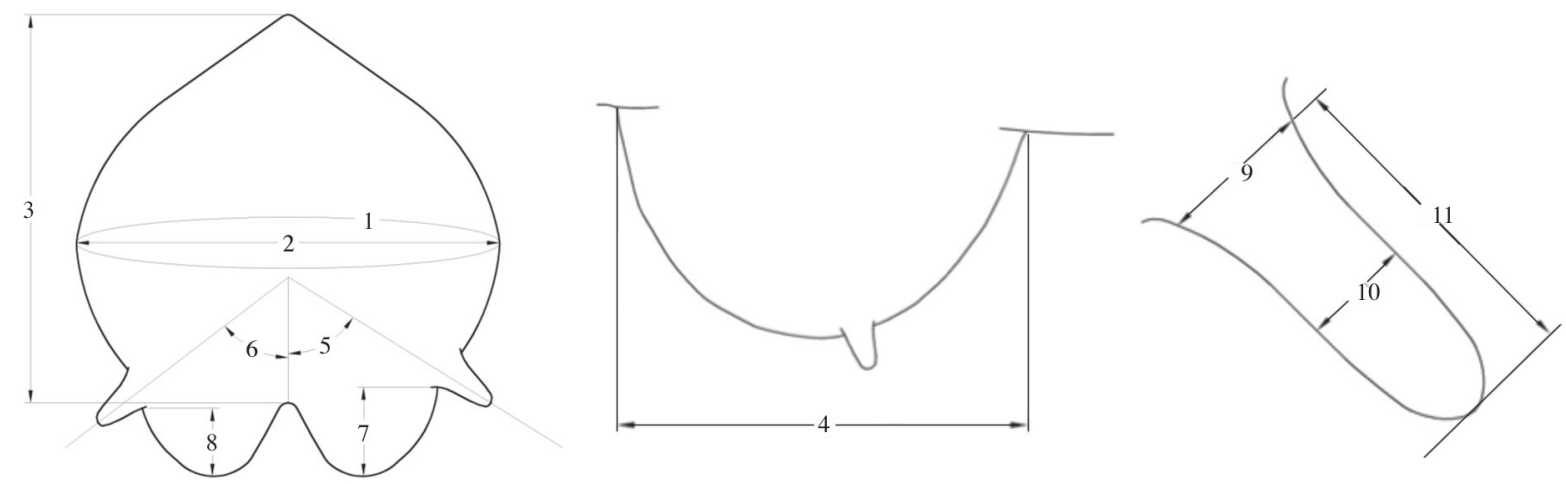

Figure 1. Morphological parameters measured on udder and teats: udder circumference (1), width (2), height (3) and length (4); angle of right (5) and left (6) teats, teat opening $(5+6)$; height of right (7) and left (8) cisterns; width at the base (9), width at the medium point (10), and length (11) of the right teat. 
Ej(i) $=$ effect of the ewe $\mathrm{j}$ within breed $\mathrm{i} ; \mathrm{Lk}=$ effect of test day number or stage of lactation (four levels: 15, 45, 75, and $105 \mathrm{~d}$ postpartum); and eijk = effect of residual error.

The interactions breed $\mathrm{x}$ stage of lactation were not significant $(\mathrm{P}>0.05)$, therefore were not included in the statistical model.

The repeatabilities of traits studied (as degree of similarity among successive measures within each ewe) were estimated using the VARCOMP procedure and the REML method (SAS, 2008), and defined as the ratio of ewe variance to the sum of the residual and ewe variances, from the above-mentioned statistical model.

\section{RESULTS AND DISCUSSION}

Tables 1, 2, and 3 show results of ANOVA for udder traits and milk yield (Table 1), teat traits (Table 2), and cistern traits (Table 3), respectively. Sheep within flock and stage of lactation significantly contributed to variation of the most of traits involved in this study. The breed had also a significant effect on udder circumference $(\mathrm{P}<0.01)$, udder length $(\mathrm{P}<0.01)$, teat opening $(\mathrm{P}<0.10)$ and milk yield $(\mathrm{P}<0.001)$, but not for the rest of studied traits $(\mathrm{P}>0.05)$. Indeed, Chilota breed evidenced greater values for udder circumference $(432.5 \mathrm{~mm})$, udder length $(86.3 \mathrm{~mm})$ and teat opening $\left(96.0^{\circ}\right)$ than Suffolk Down ewes $(410.3 \mathrm{~mm}$, $76.9 \mathrm{~mm}$, and $93.1^{\circ}$, respectively) (Table 4), but smaller than those reported in other dairy breeds as Churra (465.5 $\mathrm{mm}, 93.0 \mathrm{~mm}$, and $100.8^{\circ}$, respectively) (Fernández et al., 1995) or Awassi crosses (469.0 mm, $132.1 \mathrm{~mm}$, and $107.8^{\circ}$, repectively) (Gonzalo, 1984). Milk yield was also greater in Chilota $\left(946.5 \mathrm{~mL} \mathrm{~d}^{-1}\right)$ than in Suffolk Down $\left(558.7 \mathrm{~mL} \mathrm{~d}^{-1}\right)$, but smaller than in Churra $(1.103 \mathrm{~mL}$ $\mathrm{d}^{-1}$ ) (Fernández et al., 1995) or Awassi crosses (1.520 $\mathrm{mL} \mathrm{d}^{-1}$ ) (Gonzalo, 1984). However, milk production of Chilota was similar to or even higher than that reported for dairy Mediterranean breeds, as Tsigay $(906 \mathrm{~mL}$ $\mathrm{d}^{-1}$ ), Karagouniko (914 $\left.\mathrm{mL} \mathrm{d}^{-1}\right)$, Lacaune $\left(942 \mathrm{~mL} \mathrm{~d}^{-1}\right)$, Manchega $\left(743 \mathrm{~mL} \mathrm{~d}^{-1}\right)$ or Churra $\left(854 \mathrm{~mL} \mathrm{~d}^{-1}\right)$, in the second parity, in M4 project of Food and Agricultural Organization (Labussière, 1983; 1988). This indicates a suitable dairy potential of Chilota sheep, which can be improved by selection in a similar way to happened with previous Mediterranean breeds, in which selection programs were developed 15-20 yr ago.

The mammary traits that showed significant linear correlations with milk yield were udder circumference ( $\mathrm{r}$ $=0.40, \mathrm{P}<0.001)$ and udder width $(\mathrm{r}=0.22, \mathrm{P}<0.05)$, similarly to other dairy breeds, as Awassi (Iñiguez et al., 2009).

The rest of morphological traits were no affected by breed factor, despite milk yield differences between Chilota and Suffolk Down. In this sense, the milk yield effect was rarely significant for teat and cistern traits,

Table 1. Analyses of variance for variation factors in udder traits and milk yield.

\begin{tabular}{lrccccc}
\hline Variation sources & df & Circumference & Width & Height & Length & Milk yield \\
\hline Breed & 1 & $7.27^{* *}$ & $1.23^{\mathrm{NS}}$ & $0.17^{\mathrm{NS}}$ & $7.05^{* *}$ & $38.75^{* * *}$ \\
Stage of lactation & 3 & $17.62^{* * *}$ & $5.53^{* *}$ & $5.02^{* *}$ & $2.83^{*}$ & $12.53^{* *}$ \\
Sheep (breed) & 16 & $6.94^{* * *}$ & $5.89^{* * *}$ & $4.51^{* * *}$ & $1.88^{*}$ & $2.24^{*}$ \\
\hline
\end{tabular}

${ }^{*} \mathrm{P}<0.05 ;{ }^{* *} \mathrm{P}<0.01 ;{ }^{* * *} \mathrm{P}<0.001 ;$ NS: non significant.

Table 2. Analyses of variance for variation factors in teat traits.

\begin{tabular}{lcccccc}
\hline Variation sources & df & $\begin{array}{c}\text { Width at } \\
\text { the base }\end{array}$ & $\begin{array}{c}\text { Width at } \\
\text { medium point }\end{array}$ & Length & Right angle & Left angle \\
\hline Breed & 1 & $0.28^{\mathrm{NS}}$ & $0.01^{\mathrm{NS}}$ & $0.14^{\mathrm{NS}}$ & $0.91^{* *}$ & $2.23^{\mathrm{NS}}$ \\
Stage of lactation & 3 & $8.39^{* * *}$ & $7.61^{* * *}$ & $5.67^{* *}$ & $2.39^{\mathrm{NS}}$ & $0.33^{\mathrm{NS}}$ \\
Sheep (breed) & 16 & $2.19^{*}$ & $1.81^{*}$ & $3.64^{* * *}$ & $4.01^{* * *}$ & $2.24^{* *}$ \\
\hline
\end{tabular}

${ }^{*} \mathrm{P}<0.05 ;{ }^{* *} \mathrm{P}<0.01 ;{ }^{* * *} \mathrm{P}<0.001 ; \mathrm{NS}:$ non significant.

Table 3. Analyses of variance for variation factors in cistern traits.

\begin{tabular}{lcccc}
\hline Variation sources & df & Teat opening & Right cistern height & Left cistern height \\
\hline Breed & 1 & $2.89^{\dagger}$ & $0.22^{\mathrm{NS}}$ & $2.08^{\mathrm{NS}}$ \\
Stage of lactation & 3 & $0.59^{\mathrm{NS}}$ & $9.81^{* * *}$ & $10.63^{* * *}$ \\
Sheep (breed) & 16 & $5.03^{* * *}$ & $2.96^{* *}$ & $3.29^{* * *}$ \\
\hline
\end{tabular}

$\dagger \mathrm{P}<0.10 ;{ }^{*} \mathrm{P}<0.05,{ }^{* *} \mathrm{P}<0.01 ;{ }^{* * *} \mathrm{P}<0.001$; NS: non significant. 
Table 4. Least square means and standard error (SE) for udder traits and yield studied depending on breed and statistical significance.

\begin{tabular}{|c|c|c|c|c|}
\hline Variable & Chilota & Suffolk & SE & $F$ \\
\hline \multicolumn{5}{|l|}{ Udder } \\
\hline Circumference, $\mathrm{mm}$ & 432.5 & 410.3 & 5.83 & $7.27^{* *}$ \\
\hline Width, mm & 115.8 & 111.6 & 2.67 & $1.23^{\mathrm{NS}}$ \\
\hline Height, mm & 118.9 & 117.6 & 2.07 & $0.17^{\mathrm{NS}}$ \\
\hline Length, $\mathrm{mm}$ & 86.3 & 76.9 & 2.49 & $7.05^{* *}$ \\
\hline \multicolumn{5}{|l|}{ Teats } \\
\hline Width at the base, $\mathrm{mm}$ & 14.1 & 13.8 & 0.40 & $0.28^{\mathrm{NS}}$ \\
\hline Width at medium point, $\mathrm{mm}$ & 9.9 & 9.9 & 0.30 & $0.01^{\mathrm{NS}}$ \\
\hline Teat length, $\mathrm{mm}$ & 22.6 & 22.8 & 0.37 & $0.14^{\mathrm{NS}}$ \\
\hline Right teat angle, $\left({ }^{\circ}\right)$ & 47.8 & 46.8 & 0.76 & $0.91^{\mathrm{NS}}$ \\
\hline Left teat angle, $\left({ }^{\circ}\right)$ & 48.2 & 46.3 & 0.88 & $2.23^{\mathrm{NS}}$ \\
\hline \multicolumn{5}{|l|}{ Udder cistern } \\
\hline Teat opening, $\left(^{\circ}\right)$ & 96.0 & 93.1 & 1.20 & $2.89^{\dagger}$ \\
\hline Right cistern height, mm & 8.7 & 9.0 & 0.41 & $0.22^{\mathrm{NS}}$ \\
\hline Left cistern height, mm & 8.6 & 7.7 & 0.46 & $2.08^{\mathrm{NS}}$ \\
\hline \multicolumn{5}{|l|}{ Yield } \\
\hline Milk yield, $\mathrm{mL} \mathrm{d}^{-1}$ & 946.5 & 558.7 & 44.05 & $38.75^{* * *}$ \\
\hline
\end{tabular}

$\dagger \mathrm{P}<0.10 ;{ }^{*} \mathrm{P}<0.05,{ }^{* *} \mathrm{P}<0.01 ;{ }^{* * *} \mathrm{P}<0.001 ;$ NS: non significant.

as reported in other breeds, as Churra (Fernández et al., 1995). Chilota and Suffolk Down sheep showed teats which were shorter (22.6 and $22.8 \mathrm{~mm}$, respectively) and narrower (width at the base: $14.1 \mathrm{~mm}$ and $13.8 \mathrm{~mm}$, and width at medium point: $9.9 \mathrm{~mm}$ ) than those reported in other Spanish breed, as Castellana (length: $30.3 \mathrm{~mm}$; width at the base: $19.1 \mathrm{~mm}$ ) (Gonzalo, 1984) or Churra (length: $38.3 \mathrm{~mm}$; width at medium point: $19.3 \mathrm{~mm}$ ) (Fernández et al., 1995). Small teats could make difficult ewe milkability, although a teat size increase can be expected by milk yield selection.

Both breeds show a symmetric udder (Table 4) with similar angles for right and left teats in Chilota $\left(48.2^{\circ}\right.$ and $\left.47.8^{\circ}\right)$ and Suffolk Down $\left(46.3^{\circ}\right.$ and $\left.46.8^{\circ}\right)$, although Suffolk Down breed was imbalanced for cistern height (7.7 and 9.0 $\mathrm{mm})$. Breeds studied showed a cistern size smaller than specialized dairy sheep (Fernández et al., 1995; Iñiguez et al., 2009). Despite this fact, the teat angle and the small cistern size were compatible with a good morphological aptitude for the milking, particularly in Chilota, which evidenced a higher milk yield than Suffolk Down.

The stage of lactation was a very important effect for traits studied (Table 5). The traits defining udder size (udder circumference, width, and length) diminished throughout lactation, this reduction being particularly evident at $105 \mathrm{~d}$ postpartum. This udder size variation was compatible with the reduction of milk yield potential, which diminished from $945.0 \mathrm{~mL} \mathrm{~d}^{-1}$ (15 d postpartum) to $455.3 \mathrm{~mL} \mathrm{~d}^{-1}$ (105 d postpartum). As lactation continued the height udder increased $(\mathrm{P}<0.05)$ from $15 \mathrm{~d}(110.8 \mathrm{~mm})$ to $75 \mathrm{~d}(125.3 \mathrm{~mm})$ postpartum, but this trait diminished $(\mathrm{P}<0.05)$ in the later control at $105 \mathrm{~d}$ postpartum $(115.0$ $\mathrm{mm}$ ) coinciding with the involution of mammary gland at end of lactation. The cistern height, teat length, and teat diameters significantly diminished throughout lactation, although the stage of lactation did not affect $(\mathrm{P}>0.05)$ the teat angles (Table 5).

Establishing lactation curve can be of interest to the study of the accuracy of the milk yield and lactational measures obtained from test day records. The maximum secretion potential of the ewes resulted at 15 $\mathrm{d}$ postpartum. The decreases of milk production between successive $\left(1^{\text {st }}\right.$ and $2^{\text {nd }}, 2^{\text {nd }}$ and $3^{\text {rd }}$, and $3^{\text {rd }}$ and $\left.4^{\text {th }}\right)$ test day observations were $5.6 \%, 19.4 \%$, and $36.6 \%$, respectively; which indicated a progressive diminution of lactation curve persistency throughout lactation. Total milk yield calculated from lactation curve (according methodology of Gonzalo et al., 2003) averaged 113.5 and $67.0 \mathrm{~L}$ for Chilota and Suffolk ewes, respectively.

The repeatabilities of morphological traits (Table 6) were high for the udder circumference (0.60) and udder width (0.55), medium-high for cistern height and teat length $(0.37$ to 0.50$)$, and medium-low for teat width (0.17 to 0.23$)$, udder length (0.18) and milk yield (0.24). The reference method for udder volume estimation by measurement of water volume evacuated after udder immersion in a container filled to the brim with tepid water, is erroneous and very laborious. The udder circumference, 
Table 5. Least square means and standard error (SE) for udder traits and yield studied depending on lactation stage and statistical signification.

\begin{tabular}{|c|c|c|c|c|c|c|}
\hline Variable & $15 \mathrm{~d}$ & $45 \mathrm{~d}$ & $75 \mathrm{~d}$ & $105 \mathrm{~d}$ & SE & $F$ \\
\hline \multicolumn{7}{|l|}{ Udder } \\
\hline Circumference, $\mathrm{mm}$ & $445.0 \mathrm{a}$ & $443.3 \mathrm{a}$ & $426.1 \mathrm{a}$ & $371.1 \mathrm{~b}$ & 8.24 & $17.62^{* * *}$ \\
\hline Width, mm & $117.4 \mathrm{a}$ & $118.9 \mathrm{a}$ & $118.0 \mathrm{a}$ & $100.4 b$ & 3.77 & $5.53^{* *}$ \\
\hline Height, mm & $110.8 \mathrm{a}$ & $121.9 \mathrm{bcd}$ & $125.3 \mathrm{~d}$ & $115.0 \mathrm{ac}$ & 2.93 & $5.02^{* *}$ \\
\hline Length, mm & $90.4 \mathrm{a}$ & $77.9 \mathrm{~b}$ & $80.0 \mathrm{~b}$ & $78.3 b$ & 3.52 & $2.83^{*}$ \\
\hline \multicolumn{7}{|l|}{ Teats } \\
\hline Width at the base, mm & $16.4 \mathrm{a}$ & $13.5 b$ & $13.4 \mathrm{~b}$ & $12.6 b$ & 0.58 & $8.39^{* * *}$ \\
\hline Width at medium point, $\mathrm{mm}$ & $11.6 \mathrm{a}$ & $9.4 b$ & $9.4 \mathrm{~b}$ & $8.9 b$ & 0.43 & $7.61^{* * * *}$ \\
\hline Teat length, mm & $24.0 \mathrm{a}$ & $22.9 \mathrm{a}$ & $22.7 \mathrm{a}$ & $21.0 \mathrm{~b}$ & 0.52 & $5.67^{* *}$ \\
\hline Right teat angle, $\left({ }^{\circ}\right)$ & $49.6 \mathrm{a}$ & $47.2 \mathrm{a}$ & $46.8 \mathrm{a}$ & $45.6 \mathrm{a}$ & 1.08 & $2.39^{\mathrm{NS}}$ \\
\hline Left teat angle, $\left({ }^{\circ}\right)$ & $46.9 \mathrm{a}$ & $46.6 \mathrm{a}$ & $47.3 \mathrm{a}$ & $48.2 \mathrm{a}$ & 1.25 & $0.33^{\mathrm{NS}}$ \\
\hline \multicolumn{7}{|l|}{ Udder cistern } \\
\hline Teat opening, $\left({ }^{\circ}\right)$ & $96.5 \mathrm{a}$ & $93.8 \mathrm{a}$ & $94.2 \mathrm{a}$ & $93.8 \mathrm{a}$ & 1.70 & $0.59^{\mathrm{NS}}$ \\
\hline Right cistern height, $\mathrm{mm}$ & $11.6 \mathrm{a}$ & $7.9 b$ & $8.4 \mathrm{~b}$ & $7.7 b$ & 0.59 & $9.81^{* * *}$ \\
\hline Left cistern height, mm & $11.2 \mathrm{a}$ & $7.7 b$ & $7.0 \mathrm{~b}$ & $6.6 b$ & 0.64 & $10.63^{* * *}$ \\
\hline \multicolumn{7}{|l|}{ Yield } \\
\hline Milk yield, $\mathrm{mL} \mathrm{d}^{-1}$ & $945.0 \mathrm{a}$ & $891.7 \mathrm{a}$ & $718.3 b$ & $455.3 \mathrm{c}$ & 62.30 & $12.53^{* * *}$ \\
\hline
\end{tabular}

Means on the same row with different letter differ according to least squares means test $(\mathrm{P}<0.05)$.

${ }^{*} \mathrm{P}<0.05,{ }^{* *} \mathrm{P}<0.01 ;{ }^{* * *} \mathrm{P}<0.001$

width and height were traits which could replace the udder volume measurement because they are easy to measure and have high repeatabilities (Table 6). Repeatabilities of morphological traits were similar to those found by Fernández et al. (1995) in Churra (0.17 to 0.77).

Table 6. Repeatabilities of morphological and milk yield traits involved in this study.

\begin{tabular}{lc}
\hline Variable & Repeatabilities \\
\hline Udder & \\
Circumference & 0.598 \\
Width & 0.550 \\
Height & 0.467 \\
Length & 0.181 \\
Teats & \\
Width at the base, mm & 0.229 \\
Width at medium point, mm & 0.169 \\
Teat length & 0.398 \\
Right teat angle & 0.429 \\
Left teat angle & 0.262 \\
Udder cistern & \\
Teat opening & 0.501 \\
Right cistern height & 0.488 \\
Left cistern height & 0.365 \\
Yield & \\
Estimated milk yield & 0.237 \\
\hline
\end{tabular}

\section{CONCLUSIONS}

The Chilota sheep evidenced a greater uddercircumference, udder length, and teat opening than Suffolk Down sheep; the milk yield being 69\% higher than Suffolk Down. These results show an adequate dairy potential of Chilota ewes and a solid base to yield diversification (meat-milk) or dairy selection, although the milking morphological aptitude could be hindered by a small teats. The udder circumference seemed to be a morphological trait of great interest based on its breed discriminatory power for dairy aptitude, relationship with milk yield, easy and rapid estimation, and high repeatability.

\section{RESUMEN}

Morfología mamaria y producción lechera de las razas ovinas Chilota y Suffolk Down. Los caracteres morfológicos de la ubre (perímetro, anchura, longitud y altura), de los pezones (ángulo de inclinación, longitud y anchura), de las cisternas mamarias (apertura de los pezones y altura de la cisterna) y la producción lechera fueron medidos a lo largo de una lactación en un total de 18 ovejas del mismo rebaño (Centro Experimental INIA Butalcura, Chiloé, Chile), nueve de raza Chilota y nueve de raza Suffolk Down. El análisis de varianza mostró efectos significativos de la raza, la oveja dentro de la raza y del estado de lactación sobre las variables estudiadas. 
La raza Chilota evidenció un mayor perímetro de la ubre (433 mm), longitud de la ubre (86 mm), abertura de los pezones $\left(96^{\circ}\right)$, y producción lechera $\left(947 \mathrm{~mL} \mathrm{~d}^{-1}\right)$ que la Suffolk Down $\left(410 \mathrm{~mm}, 77 \mathrm{~mm}, 93^{\circ}\right.$, y $559 \mathrm{~mL} \mathrm{~d}^{-1}$, respectivamente). El perímetro, longitud y anchura de la ubre, junto con la altura de las cisternas y el tamaño de los pezones disminuyeron significativamente a medida que avanzó la lactación. Las repetibilidades de todos los caracteres estudiados oscilaron entre 0.17 y 0.60 . La mayor repetibilidad se encontró en el perímetro de la ubre; este carácter es fácil de medir y posee poder discriminante para la diferenciación racial. Se concluye que la raza Chilota posee una aptitud lechera superior a la Suffolk Down y similar a la de las razas españolas y mediterráneas al inicio de sus programas de selección lechera.

Palabras clave: morfología mamaria, pezones, lechería, oveja.

\section{LITERATURE CITED}

Casu, S., I. Pernazza, and A. Carta. 2006. Feasibility of a linear scoring meted of udder morphology for the selection scheme of Sardinian sheep. Journal of Dairy Science 89:2200-2209.

De La Barra, R., A. Carvajal, H. Uribe, M.E. Martinez, C. Gonzalo, J. Arranz, and F. San Primitivo. 2010. El ovino criollo Chilote y su potencial productivo. Animal Genetic Resources. FAO. Accepted.

De La Fuente, L.F., G. Fernández, and F. San Primitivo. 1996. A linear evaluation system for udder traits of dairy ewes. Livestock Production Science 45:171178.

Doney, J.M., J.N. Peart, W.F. Smith, and F. Louda. 1979. A consideration of the techniques for estimation of milk yield by suckled sheep and a comparison of estimated obtained by two methods in relation to the effect of breed, level of production and stage of lactation. Journal of Agricultural Science 92:123-132.

Fernández, G., P. Álvarez, F. San Primitivo, and L.F. de la Fuente. 1995. Factors affecting variation of udder traits of dairy ewes. Journal of Dairy Science 78:842849.

Gonzalo, C. 1984. Contribución al estudio del ordeño manual y mecánico del ganado ovino en la región Castellano-Leonesa. Tesis Doctoral. Universidad de Murcia, Murcia, España.
Gonzalo, C., M.H. Othmane, J.A. Fuertes, L.F. De La Fuente, and F. San Primitivo. 2003. Losses of precision associated with simplified designs of milk recording for dairy ewes. Journal of Dairy Research 70:441-444.

Iñiguez, L., M. Hilali, D.L. Thomas, and G. Jesry. 2009. Udder measurements and milk production in two Awassi sheep genotypes and their crosses. Journal of Dairy Science 92:4613-4620.

Labussière, J. 1983. Étude des aptitudes laitières et de la facilité de traite de quelques races de brebis du «Bassin Méditerranéen». Projet M4 FAO. p. 730-792. Proceedings $3^{\text {th }}$ International Symposium Machine Milking of Small Ruminants. Com. Español, SeverCuesta Valladolid, Spain.

Labussière, J. 1988. Review of physiological and anatomical factors influencing the milking ability of ewes and the organization of milking. Livestock Production Science 18:253-273.

Labussière, J., D. Dotchewski, et J.F. Combaud. 1981. Caractéristiques morphologiques de la mamelle des brebis Lacaune. Méthodologie pour l'obtention des données. Relations avec l'aptitude à la traite. Annales de Zootechnie 30:115-136.

Marie-Etancelin, C., J.M. Astruc, D. Porte, H. Larroque, and C. Robert-Granié. 2005. Multiple-trait genetic parameters and genetic evaluation of udder-type traits in Lacaune dairy ewes. Livestock Production Science 97:211-218.

Rogers, G.W., and S.B. Spencer. 1991. Relationships among udder and teat morphology and milking characteristics. Journal of Dairy Science 74:41894194.

SAS. 2008. SAS user's guide: Statistics. Release 9.1. 2008. SAS Institute, Cary, North Carolina, USA.

Seykora, A.J., and B.T. McDaniel. 1985. Heritabilities of teat traits and their relationships with milk yield, somatic cell counts, and percent two-minute milk. Journal of Dairy Science 68:2670-2683.

Seykora, A.J., and B.T. McDaniel. 1986. Genetics statistics and relationships of teat and udder traits, somatic cell counts, and milk production. Journal of Dairy Science 69:2395-2407.

Vinson, W.E., R.E. Pearson, and L.P. Jonson. 1982. Relationships between linear descriptive type traits and body measurements. Journal of Dairy Science 65:995-1003. 